\title{
Another Devil of a Year
}

\author{
Myrella Roy
}

$\mathrm{O}$

nce again in 2009 the Canadian Society of Hospital Pharmacists (CSHP) worked hell-bent for leather. Our furious, yet merry quest to serve our members has left a trail of accomplishments at the trading posts of advocacy, education, information sharing, and development of standards.

The year's activities were ignited by the hiring of Barbara Wells as Coordinator of the CSHP 2015 project, a quality care program that sets a vision of pharmacy practice excellence in the year 2015, with the ultimate aim of improving the outcomes of medication therapy and patient safety (http://www.cshp.ca/ programs/cshp2015/index_e.asp). In collaboration with Dr Neil MacKinnon, CSHP presidential officer and Vision Liaison, Ms Wells has already made great strides in advancing the project, by forming a steering committee, recruiting CSHP branch champions, surveying hospital pharmacy managers across Canada about their facilities' achievement of the CSHP 2015 Goals and Objectives, distributing the CSHP 2015 baseline data to readers of the Canadian Journal of Hospital Pharmacy (in the form of a reprint of the relevant chapter from the Hospital Pharmacy in Canada 2007/2008 Report; see http://www. lillyhospitalsurvey.ca/hpc2/content/2008_report/cshp_2015.pdf), and creating a "crosswalk" to link the project to supporting literature and other Canadian standards and best practices.

In April 2009, the bright new online hosting platform of the Canadian Journal of Hospital Pharmacy (http://www.cjhponline.ca) lit up for the first time. Through this intuitive platform, CSHP members can now more easily consult and search all issues of the Journal published since 2000. As an introductory offer, CSHP is granting to nonmembers open access to all of the electronic archived and current issues until December 2010.

CSHP's Official Publications were also set alight, with numerous new and revised documents (http://www.cshp.ca/ productsServices/officialPublications/type_e.asp). The Practice Standards Steering Committee issued Drug Information Services: Guidelines (in collaboration with the Drug Information Pharmacy Specialty Network [PSN]), Entry-Level Doctor of Pharmacy Degree in Canada: Information Paper on the Potential Impact on Pharmacy Services, Medication Reconciliation: Statement on the Role of the Pharmacist (in collaboration with the Medication Reconciliation Task Force), Prescribing by Pharmacists: Information Paper, and Prescribing by Pharmacists:
Statement (the last 2 documents in collaboration with the Pharmacist Prescribing Task Force). A most prolific year!

After several years of hard work, the Association des pharmaciens des établissements de santé du Québec and CSHP were glowing with excitement when they launched the

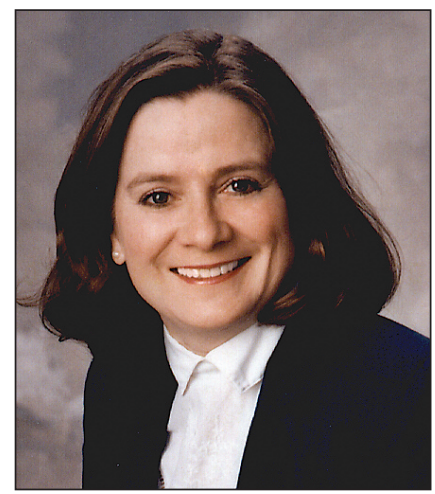
fourth edition of Care Beyond Cure, in both French and English versions (http:// www.cshp.ca/productsServices/otherPublications/careBeyondCure_ e.asp). This valued guide and its companion pocket book provide up-to-date information about the management of pain and other symptoms for the benefit of patients receiving palliative care.

In 2008 the CSHP Board of Fellows lit candles to celebrate its 40th anniversary and drafted a historical memento to recognize this significant milestone. CSHP initiated the Fellows program in 1968 to recognize CSHP members who had demonstrated outstanding leadership, dedication, and commitment to practice excellence and growth. This designation rewards the long-term, sustained effort of members in the areas of service to the Society, to patient care, to education or research, and to the practice of hospital pharmacy. The memento was initially circulated to those Fellows present at the 2008 Professional Practice Conference and was subsequently sent by e-mail to all Fellows. It was later translated into French, and in 2009, professionally designed versions were shared electronically with the entire membership (http://www.cshp.ca/programs/ fellows/anniversary_e.asp).

The Ontario Medical Association (OMA) sparked controversy within the health care community last fall with its national media campaign against pharmacists' expanding scope of practice. CSHP and its Ontario Branch responded to the inflammatory messages in a letter to the OMA, with copies to the Ontario Pharmacists' Association and the Ontario Hospital Association, urging the OMA to live up to the statement it made to the Ontario Legislative Standing Committee on Social Policy on September 29, 2009, that "collaboration between 
healthcare professionals is the best way to strengthen and enhance the delivery of safe, high quality care to patients." Similar sentiments were conveyed in a letter to the Ontario Premier, with copy to the Minister of Health and Long-Term Care, which also commended the Ontario government for passing into law the Regulated Health Professions Statute Law Amendment Act, 2009. This new law expands the services that pharmacists can offer to residents of Ontario (http://www.health.gov.on.ca/ english/public/legislation/regulated/regulated_health_ professions.html). You can read related documents on CSHP's website at http://www.cshp.ca/advocacy/campaigns/ OMAagainstPrescribing_e.asp.

The Canadian Pharmacists Association (CPhA), CSHP, and the CSHP-CPhA Joint Primary Care PSN fired off a proposal entitled "Access to quality Drug therapy - Applying Pharmacists' knowledge to The primary care System (ADAPTS)", which Health Canada has funded to the tune of $\$ 800$ 000. The ADAPTS initiative will optimize the use of pharmacists' knowledge and skills in primary care settings and will lead to the execution of several key actions set out in the Blueprint for Pharmacy Implementation Plan. The project will run from November 2009 to March 2011.

The Society, its volunteers, and its staff devoted time and energy leading to numerous other hot accomplishments in 2009. Numerous CSHP members were appointed to serve as representatives to external organizations, including the ADAPTS Management Committee, the Blueprint for Pharmacy Steering Committee, the National Faculty for implementation of the National Opioid Use Guideline, and the Planning Committee for Canada's Forum on Patient Safety and Quality Improvement 2010, sponsored by the Canadian Patient Safety Institute. We conducted an advocacy campaign on the role of hospital pharmacists in enhancing quality and safety in medication use (http://www.cshp.ca/advocacy/campaigns/ patSafety_e.asp). In collaboration with the CSHP Alberta Branch, the Society sent a letter to the dean of the Faculty of Pharmacy and Pharmaceutical Sciences at the University of Alberta expressing concerns about the proposal for an entry- level PharmD and the impact of increased experiential training on hospital pharmacy resources. In preparation for the strategic planning session to be held by CSHP Council during summer 2010, CSHP staff surveyed members about programs and services offered by the Society. We also provided feedback to a variety of stakeholders: the Advisory Committee on Health to the Alberta Minister of Health and Wellness (in collaboration with the CSHP Alberta Branch, for the principles and themes that might guide the development of new health legislation; see http://www.cshp.ca/advocacy/ABhealth_e.asp), the Canadian Council on Continuing Education for Pharmacy (for the draft Policy on the Accreditation of Certificate Programs), Health Canada (for the Electronic Ordering of Controlled Substances [Interim Guidelines]), and the Institute for Safe Medication Practices Canada (for the draft document Working with Consumers to Prevent Medication Incidents - A Consumer Reporting and Learning Strategy for the Canadian Medication Incident Reporting and Prevention System).

Of more immediate interest to practising hospital pharmacists, CSHP rekindled the terms for the malpractice insurance policy it sponsors. As a result, coverage has been extended to pharmacist prescribing authority, at no extra charge. This addition became effective for the policy period 2009/2010.

Thirteen ardent employees have fed the fire to generate these many achievements. This past year, Robyn Rockwell (Membership Administrator) celebrated her fifth anniversary of CSHP employment, Laurie Frid (Operations Manager) returned from her pregnancy and parental leave, Desarae Davidson resumed her position as Conference Administrator, Colleen Drake accepted new responsibilities as Awards and PSN Administrator, and Julie Maillet joined our team as Office Clerk.

A devil of a year, for sure! Enough accomplishments for CSHP to light a bonfire.

Myrella Roy, BScPhm, PharmD, FCCP, is Executive Director of the CSHP. 